\title{
Improving Social Studies Learning Outcomes Through Group Investigation Learning Model Assisted with Audio-Visual Media
}

\author{
Ni Luh Ardhia Octaviyantari \\ Program Studi Pendidikan Guru Sekolah Dasar, Jurusan Pendidikan Dasar, Universitas Pendidikan Ganesha \\ Email: octaviyantari27@gmail.com
}

Ni Ketut Suarni
Program Studi Bimbingan Konseling, Jurusan Ilmu Pendidikan, Psikologi dan Bimbingan. Universitas Pendidikan Ganesha
Email: tutarni@yahoo.com

I Wayan Widiana

Program Studi Pendidikan Guru Sekolah Dasar, Jurusan Pendidikan Dasar, Universitas Pendidikan Ganesha

Email:wayan_widiana@yahoo.com

\section{A R T I C L E I N F O \\ Article history: \\ 1 Mei 2020 Received in \\ revised form \\ 11 Juni 2020 \\ Accepted 10 Juli 2020 \\ Available online 25 \\ Agustus 2020}

\section{Kata Kunci:}

Group Investigation,

Audio Visual, IPS

Keywords:

Group Investigation,

Audio Visual, IPS

\begin{abstract}
A B S T R A K
Kurang optimalnya hasil belajar siswa akibat kurang aktifnya siswa dan kurangnya variasi penggunaan model dan media pembelajaran menjadi salah satu alasan penelitian ini dilakukan. Penelitian ini bertujuan untuk menganalisis pengaruh model group investigation berbantuan media audio visual terhadap hasil belajar IPS siswa kelas V Sekolah Dasar. Penelitian ini merupakan penelitian eksperimen semu (quasi experiment) dengan desain non-equivalent post-test only control group. Populasi dalam penelitian ini adalah seluruh siswa kelas V SD dengan jumlah 129 orang. Pengambilan sampel dilakukan dengan teknik simple random sampling. Sampel penelitian ini berjumlah 35 orang untuk kelas eksperimen dan berjumlah 35 orang untuk kelas kontrol. Metode pengumpulan data yang digunakan yaitu metode tes dalam bentuk tes pilihan ganda yang sudah divalidasi. Data yang telah dikumpulkan dianalisis dengan analisis statistik deskriptif dan analisis statistik inferensial menggunakan rumus uji-t. Hasil penelitian ini menunjukkan bahwa terdapat perbedaan hasil belajar IPS antara siswa yang dibelajarkan menggunakan model group investigation berbantuan media audio visual dan siswa yang menggunakan model pembelajaran konvensional. Hal ini ditunjukkan dengan nilai thitung > tabel $(3,781>2,000)$ dengan taraf signifikansi 5\%. Sehingga $\mathrm{H}_{1}$ diterima. Berdasarkan hasil penelitian tersebut dapat disimpulkan bahwa model group investigation berbantuan media audio visual berpengaruh
\end{abstract} terhadap hasil belajar IPS. Model ini bisa digunakan guru dalam menciptakan suasana belajar yang menyenangkan sehingga dapat memberikan kontribusi yang baik dalam kegiatan pembelajaran.

\section{A B S T R A C T}

The less optimal student learning outcomes due to underactive students and the deficient of variations in the use of models and learning media is one of the reasons this research was conducted. The purpose of this research is to analyze the impact of the group investigation model assisted by audiovisual media on social studies learning outcomes of five-grade elementary school students. This research was a quasi-experimental research with a non-equivalent post-test only control group design. The population in this research was the five graders contained 129 students. Taking samples for research used a sample random sampling technique. The sample of this research were 35 students for an experimental class and 35 students for a control class. Data collection methods used were test methods with multiple-choice test forms that have been validated. Data collected were analyzed by descriptive statistical analysis and inferential statistical analysis using the t-test formula. The results of this research indicate that there are differences in social studies learning outcomes between students who were taught using the group investigation model-assisted audiovisual media and students using the conventional learning model. This is indicated by the value of $\mathrm{t}_{\text {-count }}>\mathrm{t}_{\text {-table }}(3,781>2,000)$ with a significance level of $5 \%$. So $\mathrm{H}_{1}$ is accepted. Besides, the average score of student's social studies learning outcomes in experimental class > average score of student's social studies learning outcome in control class $(23,71>21,29)$. This model can be used for teachers in creating fun learning so that they can make a good contribution to learning activities.

\section{Introduction}

Social Science is a subject area with the subject matter of social life which consists of studies such as economics, geography, sociology, history, anthropology, political science, and so on by showing social problems or symptoms that arise in society (Wahida et., al., 2019). The main purpose of social studies learning is to elaborate on the ability of students to be responsive to social problems that occur in society, have a firm mentality and are also proficient in dealing with any problems or imbalances that occur every day whether they 
happen to themselves or the community (Lestari, 2017). Social studies lessons are very important for students to master because in social studies subjects students are directed to become citizens who are democratic, responsible, and love the country. This is supported by (Dewi et al., 2019; Fauziah, 2018) which states that social studies are very important for students in their lives as citizens or themselves, by learning social studies students can become good citizens, democratic and responsible and can develop social skills that are needed by students to solve their personal or social problems. face in life in society or globally. Given the important role of social studies, social studies learning needs to be designed to provide opportunities for students to develop their knowledge, attitudes, and skills. This is in accordance with the opinion (Irfanto, 2019) that in designing social studies learning, teachers must design learning activities by choosing a learning model that can activate students, provide various learning resources so that students easily absorb information and can improve learning outcomes.

Social studies learning, which should be able to activate students in the learning process, in its implementation stuffs students with several memorizing concepts without any meaningfulness from the concept. In delivering learning material, the teacher does not use a variety of models and media, teachers tend to give lectures or assignments continuously, causing students to become bored in learning. (Sari \& Tarigan, 2017) argued that the minimal variation in the learning model used by the teacher causes students to become passive during learning. This can be seen from the number of students who are noisy in class and chatting with their peers. So when the teacher teaches, the classroom atmosphere is not conducive and the material presented by the teacher is poorly understood by students. This is in accordance with the opinion (Monika, 2018) which reveals that in the implementation of social studies learning, teachers often use conventional learning models, namely lectures. In its implementation, this conventional model is deemed ineffective, because it can make students bored and the independence of students in learning is not visible. The learning model used by the teacher is not sufficient to provide opportunities or training for students in expressing the ideas or opinions they have, so those who want to argue choose to be silent which results in no sense of curiosity in students, who choose to be silent and follow all orders from the teacher. Other than that, (Azizah, 2018) also stated that the material in social studies lessons is quite dense and broad with the process of implementing learning that still uses the memorization method so that students have difficulty understanding the content of the material to be used in long-term memory. This, of course, will greatly affect the social studies learning process and the learning outcomes achieved by students

This also happened in SD Gugus XI, Buleleng District. The social studies learning process at SD Gugus XI, Buleleng District has not met expectations. The conditions found in the field indicate that the social studies learning to package have not been carried out optimally. This is reinforced by the results of interviews, observations, and study of social studies learning documents in class V SD Gugus XI, Buleleng District. From the results of interviews, observations, and document studies conducted with grade V teachers at SD Gugus XI, Buleleng District, it was found that social studies learning outcomes were still not optimal. This can be seen from the data on the midterm test scores in the social studies subject which are presented in Table 1.

Table 1. Middle Semester Test Values for Social Sciences Subjects for Class V SD Gugus XI, Buleleng District

\begin{tabular}{|c|c|c|c|c|c|c|c|}
\hline \multirow[b]{2}{*}{ No } & \multirow[b]{2}{*}{ School } & \multirow[b]{2}{*}{ Class } & \multirow[b]{2}{*}{$\begin{array}{c}\text { Students' } \\
\text { amount }\end{array}$} & \multirow[b]{2}{*}{$\begin{array}{c}\mathbf{K K} \\
\mathbf{M}\end{array}$} & \multicolumn{3}{|c|}{ Criteria } \\
\hline & & & & & $\begin{array}{c}\text { Enoug } \\
h \\
(70-79)\end{array}$ & $\begin{array}{c}\text { Good } \\
(\mathbf{8 0 - 8 9})\end{array}$ & $\begin{array}{c}\text { Very Good } \\
(90-100)\end{array}$ \\
\hline \multirow{2}{*}{1} & \multirow{2}{*}{ SD Lab Undiksha } & $\mathrm{VA}$ & 35 students & 70 & 23 & 8 & 4 \\
\hline & & V B & 34 students & 70 & 23 & 6 & 5 \\
\hline 2 & SD Negeri 1 Kampung Anyar & $\mathrm{V}$ & 17 students & 70 & 10 & 7 & - \\
\hline 3 & SD Negeri 3 Kampung Anyar & $\mathrm{V}$ & 17 students & 70 & 12 & 5 & - \\
\hline 4 & SD Negeri 1 Kampung Bugis & $\mathrm{V}$ & 25 students & 70 & 16 & 7 & 2 \\
\hline \multicolumn{3}{|c|}{ Total } & 128 & - & 84 & 33 & 11 \\
\hline
\end{tabular}

(Source: Class V teacher at SD Gugus XI, Buleleng District)

Judging from Table 1, in general, student scores already include the KKM set by the school. However, when viewed b SD (2018: 47) with KKM 70 student scores can be categorized for grades <70 are categorized as "need guidance", 70-79 scores are categorized as "sufficient", 80-89 scores are categorized as "good", and 90100 scores are categorized as "very good". So that from 128 students there are still 84 students in the sufficient category, 33 students in the good category, and 11 students in the very good category. Based on observations and interviews conducted, this was influenced by (1) students were less interested in participating in classroom learning, (2) the media used in learning was still lacking, (3) student scores in social studies subjects were still not optimal, (4) the model used by the teacher in teaching tends to be monotonous, the teacher uses the lecture 
method more often, (5) when the learning process is still dominated by the use of a blackboard without any other assistive media, (6) students do not actively participate in learning which results in less effective learning, (7) the focus of students during learning is still not good.

The situation as described above will certainly affect student learning outcomes, if this situation continues it will have an impact on student learning outcomes. (Husadati, 2019) states that learning outcomes are the acquisition of several student experiences in the affective, cognitive, and psychomotor domains. The cognitive domain (knowledge) is concerned with knowing the extent to which students understand the concept of the material being studied. The psychomotor domain (skills) is an assessment of physical activities as in practice. The affective domain (attitude) is an assessment of behavior to form good character, if it is good it needs to be improved again by the teacher. Of course, in the implementation of the learning process, several factors can affect learning outcomes including internal factors and external factors. According to Susanto (Septiana \& Hayati, 2019) Internal factors, namely factors originating from students that affect their learning abilities which include: intelligence, persistence, habits, interests, motivation to learn, as well as physical and health conditions. While external factors, namely factors originating from outside the students that can affect learning outcomes include: family, school, and society. So that in the implementation of the learning process these factors need to be considered to create meaningful learning and can improve student learning outcomes.

One way that can be used to create meaningful learning is by using variations in the use of learning models and media. (Astra, 2015) revealed that there are many strategies in the collaborative learning model such as discussion, reciprocal teaching, problem-solving, infographic management, and writing. One learning model that could increase student participation and creativity that could be used as the group investigation model. The group investigation model was a learning model that involved students actively both in planning and in the problem-solving process. The Group Investigation model is suitable because it has a constructivist theoretical basis proposed by Piaget and Vygotsky, where this theory describes a teaching and learning perspective in which students construct meaning from experiences and interactions with others and the role of the teacher is to provide meaningful experiences for students (Almeda \& Sahyar, 2017)

According to (Wahyuni 2018) argued that in the application of the group investigation model, students were active in exploring, building, and developing concepts, and the teacher was only a facilitator, guide, and motivation to students. So that student are required to be active and responsible for the group from the beginning to the end of the lesson. The model group investigation steps according to (Lasfeto (2018) divided into six stages, namely Stage 1: Identifying the topic and determining students into several groups; Stage 2: Plan the tasks to be studied; Stage 3: Carry out an investigation; Stage 4: Preparation of the final report; Stage 5: Presentation of the final report; Stage 6: Evaluation. The implementation of these steps will certainly increase student productivity and creativity. This is in accordance with the opinion (Anas (2018) namely the group investigation model led students to construct their knowledge based on their activities and learning experiences. Students choose a topic; make questions to conclude, and criticize the results of their questions so that students are trained to be diligent, thorough, honest, and open, and curious to get accurate data.

As for the advantages of the group investigation learning model according to Slavin (Putra et al., 2019; Arlinda et al., 2019) is this method can think at high levels, trains students to foster the ability to think independently, active student involvement can be seen from the first stage to the last stage of learning, and the application of this learning method students are happy and feel they enjoy the learning process. Some studies that found that the group investigation model affected learning outcomes, namely research conducted by (Sumardha (2019) with the title Influence of Group Investigation Model on Student Learning Outcomes in Social Studies Learning in Elementary Schools. This study states that there is an effect of the group investigation model on student learning outcomes in social studies learning in grade V elementary school, this can be seen from the average student learning outcomes using the group investigation model which is higher than the average student learning outcomes without using the group investigation model. This research is related to the research to be carried out, namely the use of the group investigation model and also the social studies learning outcomes.

Further research conducted by (Sangadji, 2016) entitled Implementation Of Cooperative Learning With Group Investigation Model To Improve Learning Achievement Of Vocational School Students In Indonesia. This study stated that the group investigation model affected learning achievement in economic training seen from an increase in the students' initial average score. This research is related to the research to be carried out, namely the use of the group investigation model, but the research that will be carried out examines the social studies learning outcomes. Other research conducted by (Anas, 2018) with the title "Application of Type Cooperative Learning Models Group Investigation (GI) in Improving Competence Learning Biology Student School". The results of this study indicated that there was an increase in cognitive competence in the cognitive, affective, and psychomotor aspects so that the group investigation model could improve the competence of learning biology. The difference between this research and the research to be carried out is that this research examines the competence of learning biology while the research that will be carried out examines the social 
studies learning outcomes but the similarities are using the group investigation model. So from some of these studies, it can be seen that the group investigation model affects learning outcomes.

If the group investigation model is combined using audio-visual media, learning will be more interesting, because audio-visual media is a combination of audio media that involves hearing and visual media that involves vision that is displayed simultaneously so that it can attract students' attention and focus students on the material which he will study. According to (Mayasari \& Sulfemi, 2019), Audio-visual media is an intermediary medium for presenting material that is used through sight and hearing to help students gain certain attitudes, knowledge, or skills. Audiovisual media used in this research is video media. (Pramana \& Suarjana 2018; Diana et al., 2018) (Video media can be defined as any format of electronic media that is used to stimulate students' thoughts, feelings, and interests in learning through displaying ideas, messages, and information on moving pictures. The use of video media in the learning process will make students interested and focused on taking part in learning.

The use of video media in the group investigation model was used to provide an initial overview of the topics that students would later discuss so that students could be more focused and focused on learning the topics to be selected. Of course, the application of the group investigation model assisted by audio-visual media will be able to increase student participation and activities in participating in learning. Thus, the group investigation model assisted by audio-visual media was suspected to affect social studies learning outcomes. In classroom learning, the group investigation model had several learning steps. (Trianto, 2010) the steps for the group investigation model were (1) Topic Selection. The teacher determines the problem that will be discussed by the students. Divide students into groups heterogeneously. (2) Teacher Cooperative Planning explains learning procedures and assignments for students. The teacher distributes worksheets and assigns students to carry out investigations (investigations). (3) Implementation. The teacher follows the progress of each group and offers assistance when needed. (4) Analysis and synthesis. The teacher monitors students in making presentation materials (5) Presentation of the results The teacher coordinates students in making the Phase-6 presentation of Teacher Evaluation together with students summarizing the subject matter. This study aims to determine the effect of the group investigation model assisted by audio-visual media on the social studies learning outcomes of fifth-grade elementary school students in the 2019/2020 academic year. This study is different from existing research, namely this research innovates with the aid of audio-visual media. With the application of this model, it is hoped that the problem of learning outcomes in SD Gugus XI, Buleleng District, Buleleng Regency can be overcome.

\section{Method}

This research was conducted in class V SD Gugus XI, Buleleng District, Buleleng Regency, which consisted of 4 schools, namely SD Lab Undiksha Singaraja, SD N 1 Kampung Anyar, SD N 3 Kampung Anyar, and SD N 1 Kampung Bugis. The research was carried out in the second semester of the 2019/2020 school year. This research was a quasi-experimental study with a non-equivalent post-test only control group design.

The population in this study was class V Elementary School Cluster XI, Buleleng District, Academic Year 2019/2020. The total population in this study was 129 students, consisting of 5 classes in 4 schools, namely the VA class at Undiksha Singaraja Lab Elementary School (35 students), the VB class at Undiksha Singaraja SD Lab (35 students), SD Negeri 1 Kampung Anyar (17 students), SD Negeri 3 Kampung Anyar (35 students), and SD Negeri 1 Kampung Bugis (25 students). The sample in this study was determined using the sample random sampling technique. Before determining the sample, an equivalence test was carried out to determine whether or not the ability of grade V students in each SD was equal. The equivalence test was carried out by analyzing the value of social studies learning outcomes using the one-way analysis of variance test (ANOVA A), with the criteria if F-count> F-table then $\mathrm{H} 0$ is rejected and $\mathrm{H} 1$ is accepted so that the group was interpreted as unequal, whereas if $\mathrm{F}$-count $<\mathrm{F}$-table then $\mathrm{H} 0$ is accepted and $\mathrm{H} 1$ is rejected so that the group is interpreted equally. Based on the equivalence test at the $5 \%$ significance level, the value of F-count $<$ F-table $(0.13<2.45)$ was obtained. Thus, the group was interpreted equally. After conducting the equivalence test, it was continued with the determination of the research sample using the random sampling technique by lottery. Based on the results of the draw, a sample could be determined, namely a group of students in class VA at Undiksha Lab Elementary School as an experimental class given learning treatment with a group investigation model assisted by audio-visual media and a group of grade V B students at Undiksha Lab Elementary School as a control class given learning using a conventional model.

The data collection method in this research was the test method. The instrument used in this study was a social study learning outcome test in the form of a multiple-choice test with four answer choices (a, b, c, and d). Each question was given a score of 1 if it is answered correctly and a score of 0 if the student did not answer or the answer is wrong. The learning outcome test developed was adjusted to the cognitive ability levels of students. The basic competence measured in this study was to analyze the forms of human interaction with the environment and their effects on the social, cultural and economic development of Indonesian society, with the 
indicators used, namely the revised cognitive aspects of Bloom's taxonomy which consists of analyzing (C4) and evaluating (C5). Then, to ensure that the instrument was of good quality, an instrument test was carried out in the form of a validity test by an expert in social studies and a trial test with a total of 80 students was also carried out, after which the content validity test, the test item validity, reliability, differentiation test is carried out. and the difficulty test. From the results of the instrument test, the results obtained from the 40 test items tested, 31 items were declared valid or suitable for use in the study and 9 items were not suitable for use. The grid used in this study was developed from the basic competencies for social studies content which were developed into 11 indicators which were divided into 8 indicators for the cognitive domain at the $\mathrm{C} 4$ level and 3 indicators for the cognitive domain at the C5 level.

The data analysis method used in this research was descriptive statistical analysis method and inferential statistical analysis method. Descriptive statistical analysis functioned to classify data, complete, present, and present processed results. Meanwhile, the inferential statistical analysis served to generalize the results of the research conducted. Descriptive statistical analysis used in this study was to find the mean (average), median, mode, standard deviation, and variance, and to determine the five-rating scale. Meanwhile, inferential statistical analysis was used to test the hypothesis by using the t-test (polled variance), but before testing the hypothesis begins with a prerequisite test, namely the data distribution normality test and the homogeneity test. The calculation of the assumption test and hypothesis testing was done manually using a formula.

\section{Findings and Discussion}

The description of the research data included descriptions of the descriptive statistical computation results of the post-test experimental group, namely the group of students who took the group investigation model assisted by audio-visual media and the description of the post-test result data of the control group, namely the group of students who took conventional learning. The recapitulation of the results of the descriptive statistical calculation of the post-test scores of social studies learning outcomes is presented in table 2 .

Table 2. Recapitulation of the results of the descriptive statistical calculation of the post-test score of social studies learning outcomes

\begin{tabular}{ccccccccc}
\hline Group & N & Mean & Median & Modus & $\begin{array}{c}\text { Standard } \\
\text { Deviation }\end{array}$ & Variants & $\begin{array}{c}\text { Minimum } \\
\text { Score }\end{array}$ & $\begin{array}{c}\text { Maximum } \\
\text { Score }\end{array}$ \\
\hline Experiment & 35 & 23,71 & 24 & 24 & 2,42 & 5,84 & 18 & 28 \\
Control & 35 & 21,29 & 21 & 21 & 2,80 & 7,85 & 15 & 26 \\
\hline
\end{tabular}

Judging from table 2 shows that the results of the descriptive statistical calculation of the post-test scores of students' social studies learning outcomes obtained an average score of student social studies learning outcomes in the experimental group of 23.71 and the average score of student social studies learning outcomes in the control group was 21.29. This shows that the social studies learning outcomes of the experimental group are greater than the social studies learning outcomes of the control group. So that for the tendency of the classification of student social studies learning outcomes in the experimental group and the control group a criterion with a scale of five has been developed. For a scale of five, the experimental group with an average of 23.71 was included in the very high criteria, while for the control group with an average of 21.29 it was included in the high criteria.

Before testing the hypothesis, the assumption test is first carried out which includes the data distribution normality test and the variance homogeneity test. The distribution normality test is carried out to present that the sample comes from a normally distributed population. The data normality test was carried out by using the ChiSquare $(\chi 2)$ test at a significance level of $5 \%$ and the degrees of freedom $\mathrm{dk}=$ (number of class intervals parameter - 1). With the criteria $\chi^{2}$ count $<\chi 2$ table, the sample comes from a population that is normally distributed. Meanwhile, the variance homogeneity test aims to check the variance similarity between treatment groups. The homogeneity test was carried out using the F test with the homogeneity testing criteria, namely if Fcount <Ftable, the sample was homogeneous. The recapitulation of the results of the assumption test calculations is presented in table 3 . 
Table 3. Result of the Assumption Test Calculation

\begin{tabular}{|c|c|c|c|c|c|c|c|c|}
\hline \multirow[b]{2}{*}{ No } & \multirow[b]{2}{*}{$\begin{array}{c}\text { Group of } \\
\text { Data }\end{array}$} & \multicolumn{3}{|c|}{ Normality Test } & \multicolumn{4}{|c|}{ Homogeneity Test } \\
\hline & & $\chi^{2}$ & $\begin{array}{c}\text { Critical Value with a } \\
\text { Significance Level of } \\
5 \%\end{array}$ & Status & Variants & F-count & $F_{\text {-table }}$ & Conclusion \\
\hline 1 & $\begin{array}{l}\text { Post-test } \\
\text { Experiment } \\
\text { Group }\end{array}$ & 5,583 & 15,507 & Normal & 5,84 & & & \\
\hline 2 & $\begin{array}{l}\text { Control } \\
\text { group post- } \\
\text { test }\end{array}$ & 7,453 & 16,919 & Normal & 7,85 & 1,34 & 3,98 & Homogenous \\
\hline
\end{tabular}

Based on table 3 of the assumption test results, it was found that the social studies learning outcomes data of the experimental group and control group students were normal and homogeneous. After the assumption test results are obtained, the analysis is continued with hypothesis testing. Hypothesis testing is done using the t-test with the polled variance formula. The test criterion is that $\mathrm{H} 0$ is rejected if tcount $>\mathrm{t}$-table, where $\mathrm{t}$-table is obtained from the $\mathrm{t}$ distribution table at the $5 \%$ significance level with degrees of freedom $\mathrm{db}=\mathrm{n} 1+\mathrm{n} 2-2 \mathrm{~A}$ recapitulation of the results of the t-test analysis is presented in table 4.

Tabel 4. T-test Result

\begin{tabular}{ccccccc}
\hline Group & $\mathbf{N}$ & Mean & Variants & Db & t-count & t-table \\
\hline Experiment & 35 & 23,71 & 5,84 & \multirow{2}{*}{68} & \multirow{2}{*}{3,781} & 2,000 \\
Control & 35 & 21,29 & 7,85 & & & \\
\hline
\end{tabular}

Based on the results of the t-test above, the $\mathrm{t}$-count is 3,781. While t table is 2,000 with a significance level of $5 \%$ and $\mathrm{db}=68$. This means, $\mathrm{t}$ count $>\mathrm{t}$ table $(3,781>2,000)$ so that $\mathrm{H} 0$ is rejected and $\mathrm{H} 1$ is accepted. So there is a significant difference in social studies learning outcomes between the group studied with the group investigation model assisted by audiovisual media and the group of students who were not taught with the group investigation model assisted by audiovisual media in grade V SD Gugus XI, Buleleng District, Buleleng Regency, 2019/2020 Academic Year.

Based on the description of the data, the results showed that there were differences in learning outcomes between groups of students who were taught using the group investigation learning model assisted by audiovisual media and groups of students who were taught using conventional learning. Descriptively, the social studies learning outcomes of the experimental group were higher than those of the control group. This review is based on the average score of social studies learning outcomes. The average score of students' social studies learning outcomes in the experimental group was 23.71 which was in the very high category. Meanwhile, the control group students' social studies learning outcomes score was 21.29 which was in the high category.

Based on data analysis using t-test, it is known that $\mathrm{t}$-count $=3.781$ and $\mathrm{t}$ table $(\mathrm{db}=68$ and a significance level of $5 \%)=2,000$. The results of these calculations indicate that $\mathrm{t}$-count is greater than $\mathrm{t}$-table $(\mathrm{t}$-count $>\mathrm{t}$ table), so it means that there is a difference between the group of students who were taught using the group investigation model assisted by audio-visual media and the group of students who were taught using conventional learning models. The existence of these differences shows that the group investigation learning model assisted by audio-visual media affects social studies learning outcomes for fifth-grade elementary school students in Gugus XI, Buleleng District, Buleleng Regency, 2019/2020 academic year. The differences in social studies learning outcomes between groups of students who were taught using the group investigation model assisted by audio-visual media and groups of students who were taught using conventional learning were influenced by the following factors.

First, the learning model of the group investigation assisted by audio-visual media prioritizes student participation and activities to find material or anything about the material to be studied in the learning process. In this lesson, students are required to develop their productivity and creativity in finding material to be studied so that students are required to be active in the learning process. Of course, this is in accordance with the opinion (Arinda, 2019) that the group investigation learning model made students more active in carrying out learning and exchanging ideas because it made students learn in small group situations, where students were given responsibility for their learning, as well as other people in the group. This is confirmed by the findings by (Sangadji, 2016) which showed that the group investigation model was a learning method that made students active in learning so that the learning that took place became more meaningful and had a positive impact on student learning outcomes. 
Second, students are required to use high-level thinking skills. The involvement of the teacher in this model which only helps students plan, implement plans, and organize groups and functions as a facilitator, of course, makes students have to be able to solve their problems. This encourages students to be more active in exploring, building, and developing concepts, so that students will feel challenged to develop their ability to solve problems. This model requires students to develop critical thinking skills to dare to express their opinions in groups and train students to find their answers to the problems they face. The application of this group investigation model made students active, interested, and daring to argue in groups to learn. This is also in line with opinion (Ariawan, 2016) that the group investigation type cooperative model made students active in constructing their knowledge, able to structure and solve problems through critical, creative, analytical, and productive thinking. This is supported by the findings (Lestari, 2019) which showed that through the group investigation model students were allowed to be scientific by developing curiosity, honesty, openness, diligence, and thoroughness. The group investigation learning model provided an opportunity for students to determine their problems and required students to find solutions through systematic steps so that through this process students were trained in using critical thinking skills.

Third, students play an active role in the preparation stage to the implementation stage of the investigation. In the preparation stage, students can determine their topic issues to be discussed. By determining the topic of discussion by yourself, students will feel more challenged and motivated in studying and solving these problems. Meanwhile, at the implementation stage students are also required to find their solutions to problems from the topics that have been selected, and the teacher's role is only as a facilitator. Of course, this can foster an enthusiastic attitude towards the material presented so that it can optimize learning activities with the group which fosters self-confidence and enthusiasm for learning in students. This is in accordance with the opinion of (Jailani, 2016) that the group investigation type cooperative learning model provided the widest possible opportunity for students to be directly and actively involved in the learning process from planning to how to learn a topic through investigation. Through this model, each student is required to take a role in solving the problems in his group. In addition, the group investigation model assisted by audio-visual media had simple and interesting stages, including the teacher guiding students to form heterogeneous groups of 5-6 people, wherein each group was allowed to determine the topic to be discussed, but before that, first, the teacher showed a video about the material to be discussed to focus on students related to the material to be discussed after each group determined the topic to be discussed in more depth, the students planned the investigation process, and proceeded to prepare a report and present it to the class. (Khasanah, 2019) revealed that learning using the group investigation model had stages that made students interested and enthusiastic about taking part in learning in class. This is reinforced by the findings by (Anas, 2018) which showed that with the group investigation model students were trained to solve problems through existing steps and had been prepared with an investigation group to increase student independence in learning which would ultimately improve learning outcomes.

Fourth, the group investigation learning model assisted by audio-visual media was able to create interesting and fun learning. The application of the group investigation model combined with audio-visual media, especially video media, made learning interesting, enjoyable and made students focus on the material to be studied, thereby creating an active and meaningful learning atmosphere. Learning by applying the group investigation model assisted by audio-visual media can be interesting and focus students' attention in following the lesson because students can see and hear directly about the learning material displayed through the learning video that is displayed in front of the class. The use of audio-visual media is a good alternative in learning because, with video, it becomes easier for teachers to convey learning material to students. This is in line with opinion (Lasfeto, 2018) which states in the video media, students can see the picture as well as listen to the accompanying sound, with the functioning of these two senses, students will be able to more easily remember what is conveyed in the video so that the delivery of the message in the video will be maximized. This is confirmed by the findings (Diana et al., 2018) which states that video media will attract and direct students 'attention to concentrate on the content of the lesson, and learning will attract more students' attention.

Fifth, the group investigation learning model assisted by audio-visual media increased student cooperation. In the implementation of the learning process that demands the participation and activities of students and teachers only as facilitators, of course, requires students to take part in solving the problems of the chosen topic. Each student in his group members must cooperate in finding resources, investigating, preparing reports, and preparing presentations, so that group cooperation is needed to solve problems from the chosen topic on time. In addition, in implementing this model, it has indirectly fostered certain relationships among students, students can interact and respect their friends. This is in accordance with the opinion (Untoro, 2016) which states that the group investigation model requires students to take a role in finding sources, investigating relevant material, proposing arguments, and presenting them in their groups and the class. This is in line with the findings (Artini, 2016) which reveals that cooperation contributes to the learning experience so that students have adequate understanding after being given a learning outcome test. Based on this, it can be concluded that the group investigation model assisted by audiovisual media makes students more active in exploring, building, and 
developing concepts, and can train students in group collaboration and train students' skills when communicating and interacting. This statement is supported by (Dewi et al., 2017) that the group investigation model must involve students starting from planning, both in determining the topic and the way to study it through investigation. This is confirmed by the research conducted by (Dumilah et al., 2017) which stated that the group investigation model had more advantages than the conventional model on the social studies learning outcomes of grade II students at SD Supriyadi Semarang.

Unlike the case with the control class which was taught using conventional learning models. In learning more teachers dominate the class by delivering the material which is done through lectures, questions and answers, and continuous assignments. According to (Giri et al., 2018) learning that is carried out through lectures, questions and answers, and assignments causes students to tend to be passive and only listen to the material presented by the teacher. Learning like this can be said to be less training students to develop productivity and creativity.

In the implementation of this study, it was found that the application of the group investigation model assisted by audio-visual media could provide meaningful and fun learning for students to improve social studies learning outcomes. In the application of the group investigation model assisted by audio-visual media, students were trained to use high-level thinking skills and also think independently by directing students to be more active in exploring, building and developing concepts assisted by using audio-visual media in the form of video media which made learning interesting, fun. and make students focus on the material to be studied, thus creating an active and meaningful learning atmosphere.

Learning by applying the group investigation model assisted by audiovisual media could attract and focus students' attention in following the lesson. This is as stated by (Diana et al., 2018) learning that is carried out through lectures, questions, and answers, and assignments that cause students to tend to be passive and only listen to the material presented by the teacher. Learning like this can be said to be less training students to develop productivity and creativity.

In the implementation of this study, it was found that the application of the group investigation model assisted by audio-visual media could provide meaningful and fun learning for students to improve social studies learning outcomes. In the application of the group investigation model assisted by audio-visual media, students were trained to use high-level thinking skills and also think independently by directing students to be more active in exploring, building and developing concepts assisted by using audio-visual media in the form of video media which made learning interesting, fun. and make students focus on the material to be studied, thus creating an active and meaningful learning atmosphere.

Learning by applying the group investigation model assisted by audiovisual media could attract and focus students' attention in following the lesson. This is as stated by (Lasfeto, 2018) which states in the video media, students can see the picture as well as listen to the accompanying sound, with the functioning of these two senses, students will be able to more easily remember what is conveyed in the video so that the delivery of the message in the video will be maximized.

So from the findings during the study, the application of the group investigation learning model had a positive impact and could improve student social studies learning outcomes. The implication of this research is to improve social studies learning outcomes, the group investigation model assisted by audio-visual media can be used by teachers in creating a pleasant learning atmosphere so that it can make a good contribution in learning activities.

\section{Conclusion}

Based on the formulation of the problem and the results of the study, it can be concluded that there is a significant effect of the group investigation model assisted by audio-visual media on the social studies learning outcomes of grade V elementary school students. This can be seen from the higher score of learning outcomes in the experimental group compared to the control group. Thus, the group investigation model assisted by audiovisual media can improve social studies learning outcomes for fifth-grade students of SD Gugus XI, Buleleng District, Buleleng Regency, 2019/2020 academic year.

\section{References}

Almeda, R., \& Sahyar. (2017). Effect of Cooperative Learning Model type Group Investigation Assisted PhET to Students' Conceptual Knowledge. Journal of Research \& Method in Education, 7(4), 75-80.

Anas, Y., Anhar, A., \& Sumarmin, R. (2018). Application of Type Cooperative Learning Models Group Investigation ( GI ) in Improving Competence Learning Biology Student School. International Journal of Progressive Sciences and Technologies (IJPSAT), 6(2), 380-387. 
Ariawan, K. D., Jampel, I. N., \& Rati, N. W. (2016). Pengaruh Model Pembelajaran Kooperatif Tipe Group Investigation Berbasis Media Lingkungan Terhadap Hasil Belajar Ipa Siswa Kelas Iv Di Desa Sidetapa. EJournal PGSD Universitas Pendidikan Ganesha, 4(1), 1-10.

Arinda, Y., Wilujeng, I., \& Kuswanto, H. (2019). The Application Group Investigation (GI) Learning Model assisted Phet to Facilitate Student Scientific Work Skills. International Journal of Educational Research Review, 254-261.

Arlinda, R., Noorhapizah, \& Agusta, A. R. (2019). Meningkatkan Aktivitas Belajar Siswa Tema Benda-Benda Di Sekitar Kita Muatan PPKN Menggunakan Kombinasi Model Pembelajaran Group Investigation (GI), Numbered Head Together (NHT), dan Snowball Throwing Pada Siswa Kelas V SDN Pangeran 1 Banjarmasin. Prosiding Seminar Nasional PS2DMP ULM, 5(1), 1-10.

Artini, Pasaribu, M., \& Husain, S. M. (2015). Penerapan Model Pembelajaran Kooperatif Tipe Group Investigation untuk Meningkatkan Aktivitas dan Hasil Belajar IPS Siswa Kelas VIII di SMP Negeri 3 Singaraja Tahun Pelajaran 2015/2016. E-Jurnal Mitra Sains, 3(1), 45-52.

Astra, I. M., Wahyuni, C., \& Hadi, N. (2015). Improvement of Learning Process and Learning Outcomes in Physics Learning by using Collaborative Learning Model of Group Investigation at High School (grade X, SMAN 14 Jakarta). Journal of Education and Practice, 6(11), 75-80.

Azizah, T. N., Ruminiati, \& Zainuddin, M. (2018). Peningkatan Aktivitas dan Hasil Belajar IPS melalui Penerapan Model Mind Mapping berbasis Pendekatan SAVI. Jurnal Pendidikan: Teori, Penelitian, Dan Pengembangan, 3(1), 121-124.

Dewi, N. M. C. B., Tegeh, I. M., \& Suwatra, I. W. (2019). Hubungan Sarana Pembelajaran dan Motivasi Belajar dengan Hasil Belajar IPS. International Journal Of Elementary Education, 3(3), 335-343.

Dewi, P. P. Y., Manuaba, I. S., \& Suniasih, N. W. (2017). Pengaruh Model Pembelajaran Kooperatif Tipe Group Investigation Terhadap Hasil Belajar Ipa Siswa Kelas Iv Sekolah Dasar. International Journal of Elementary Education, 1(4), 264-271.

Diana, L. M., Sulton, \& Sulthoni. (2018). Pengaruh Model Kooperatif Numbered Head Together (NHT) Berbantuan Media Video Terhadap Keterampilan Sosial Dan Hasil Belajar Pada Mata Pelajaran IPS Kelas VIII SMP Islam Al-Hidayah Kaliwates Jember. Jinotep (Jurnal Inovasi Dan Teknologi Pembelajaran) Kajian Dan Riset Dalam Teknologi Pembelajaran, 3(2), 144-151.

Direktorat Pembinaan Sekolah Dasar. (2018). Panduan Penilaian untuk Sekolah Dasar (SD). Direktorat Jendral Pendidikan Dasar dan Menengah Kementrian Pendidikan dan Kebudayaan.

Dumilah, R., Ysh, S., \& Khusnul, F. (2017). Pengaruh Model Pembelajaran Group Investigation Terhadap Hasil Belajar IPS Kelas II SD Supriyadi Semarang. Prosiding Seminar Nasional Pendidikan 2017, 514-519.

Fauziah, R. (2018). The Effect of Cooperative Learning Model Numbered Heads Together (NHT) Type on Student Learning Outcomes in Social Sciences Subjects in Grade V Elementary School. International Journal of Educational Dynamics, 1(1), 147-154.

Giri, K. Y. Y., Suarni, N. K., \& Arini, N. W. (2018). Pengaruh Model Pembelajaran Kooperatif Script Berbantuan Media Audio Visual terhadap Hasil Belajar IPS Kelas IV. E-Journal PGSD Universitas Pendidikan Ganesha, 6(1), 63-72.

Husadati, S. D. F., Purnamasari, V., \& Royana, I. F. (2019). Pengaruh Model Circuit Learning ( CL ) Terhadap Hasil Belajar Siswa pada Mata Pelajaran IPS. International Journal of Elementary Education, 3(3), 358365.

Irfanto, W. Y., Mustajil, \& Muhammad, J. (2019). The Effect of Cooperative Two Stay Two Stray Model on Civics Learning Outcomes of Primary School Students. International Journal for Educational and Vocational Studies, 1(3), 212-216.

Irmayanti, K. M., Parmiti, D. P., \& Sudana, D. N. (2017). Pengaruh Model Pembelajaran Group Investigation Berbasis Kearifan Lokal Tri Kaya Parisudha Terhadap Hasil Belajar Ips. MIMBAR PGSD Undiksha, 5(2), $1-10$.

Jailani, S. (2016). Pengaruh Model Pembelajaran Kooperatif Tipe Group Investigasi Terhadap Hasil Belajar Matematika Siswa Kelas XI IPS MAN Pasir Pengaraian. Jurnal Ilmiah Mahasiswa FKIP Prodi Matematika, 2(2). 
Khasanah, N., Sekaringtyas, T., \& Soleh, D. A. (2019). Pengaruh Penggunaan Model Pembelajaran Kooperatif Tipe Group Investigation ( GI ) Terhadap Kecerdasan Interpersonal Siswa Dalam Pembelajaran. Dinamika IPA Sekolah Dasar, 1(1), 1-13.

Lasfeto, A. R. (2018). Meningkatkan Hasil Belajar Ipa Melalui Model Group Investigation Berbantuan Video Pada Siswa Sekolah Dasar. International Journal of Elementary Education, 2(1), 1-7.

Lestari, E., Cahyono, H., \& Awaluddin, A. (2019). Penerapan model pembelajaran group investigation pada materi lingkaran untuk meningkatkan kemampuan berpikir kritis. Jurnal Math Educator Nusantara: Wahana Publikasi Karya Tulis Ilmiah Di Bidang Pendidikan Matematika, 5(2), 124-139.

Lestari, N. K. T., Kristiantari, M. R., \& Ganing, N. N. (2017). Pengaruh model pembelajaran talking stick berbantuan lagu daerah terhadap hasil belajar IPS. Journal of Education Research and Evaluation, 1(4), 290-297.

Mayasari, N., \& Sulfemi, W. B. (2019). Peranan Model Pembelajaran Value Clarification Technique Berbantuan Media Audio Visual Untuk Meningkatkan Hasil Belajar Ips. Jurnal Pendidikan, 20(1), 53.

Monika, V. R., Kristin, F., \& Anugraheni, I. (2018). Penerapan active leraning untuk meningkatkan kemandirian belajar siswa dan hasil belajar IPS pada siswa kelas 5 SD. Jurnal Sains Dan Teknologi, 1(1), 61-69.

Pramana, I. P. Y., \& Suarjana, I. M. (2018). Pengaruh Model Pembelajaran Time Token Berbantuan Media Video Terhadap Hasil Belajar Ipa Kelas V Sd. Journal of Education Technology, 2(4), 137-144.

Putra, J. S., Johar, R., \& Ikhsan, M. (2019). Peningkatan Prestasi dan Motivasi Belajar Siswa melalui Model Pembelajaran Kooperatif Tipe Group Investigation di SMA Negri 8 Banda Aceh. Jurnal Peluang, 7(1), $116-126$.

Sangadji, S. (2016). Implementation of cooperative learning with group investigation model to improve learning Achievement of vocational school students in Indonesia. International Journal of Learning \& Development, 6(1), 91-103.

Sari, M., \& Tarigan, A. E. T. B. (2017). Improving Student Learning Outcomes In Subject IPS Using Model Numbered Heads Together On Grade IV In Elementary School. International Conference on Global Education V"Global Education, Common Wealth, and Cultural Diversity, 10, 10-11.

Septiana, V. W., \& Hayati, M. (2019). Hubungan Pemberian Reinforcement dengan Hasil Belajar Didik Kelas V Sekolah Dasar. Menara ILMU, 13(4), 148-157.

Sumardha, F. S. (2019). Pengaruh Model Group Investigation Terhadap Hasil Belajar Siswa Dalam Pembelajaran IPS di Sekolah Dasar. Jurnal Pendidikan Dan Pembelajaran, 8(8).

Untoro, B. (2016). The Effect of Group Investigation and Learning Style on Students' Writing of Analytical Exposition. IJEE (Indonesian Journal of English Education), 3(1), 29-45.

Wahida, S. N., Ramly, \& Halim, M. (2019). Perbedaan Hasil Belajar IPS Menggunakan Model Problem Based Learning (PBL) Dan Model Pembelajaran Kooperatif Tipe Number Head Together (NHT) Ditinjau Dari Kreativitas Belajar Siswa Kelas VIII SMPN 2 Raha. Jurnal Wahana Kajian Pendidikan IPS, 3(1), 42-48.

Wahyuni, N. L. ., Wibawa, I. M. ., \& N.T, R. (2018). Pengaruh Model Pembelajaran Kooperatif Tipe Group Investigation Berbantuan Media Gambar Terhadap Keterampilan. International Journal of Elementary Education, 2(3), 203-210. 